\title{
NAGY FERENC
}

Régi és új tendenciák a büntetőjogban és a büntetőjog-tudományban

MTA doktori értekezés tézisei 


\section{TARTALOM}

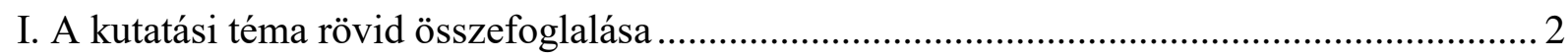

II. Az értekezés elkészítésében alkalmazott módszerek.................................................... 4

III. Az értekezés tudományos eredményeinek összefoglalása …......................................... 5

1. A büntetőjog morális/erkölcsi eredetéröl ....................................................................... 5

2. A büntetőjog(-tudomány) szellemi forrásairól ......................................................... 5

3. A szabadság és a biztonság (jog)fillozófiai hátteréröl .............................................. 6

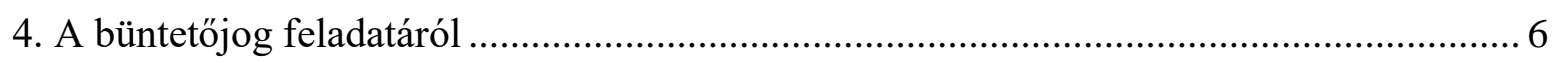

5. A magyar büntetőjog tudományáról - a (büntetőjog)tudomány ismérveiről, hazai

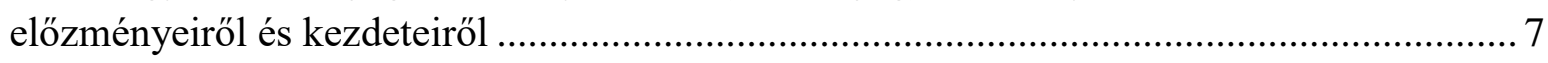

6. Az anyagi büntetőjog tudományáról hazánkban ..................................................... 9

6.1. A korai büntetőjogi kodifikációs kísérletek időszaka (1790-1848) .......................... 9

6.2. Az abszolutizmus korszaka (1848/1852-1860/1867) ........................................... 10

6.3. A klasszikus kodifikáció időszaka (1867-1878) .................................................. 10

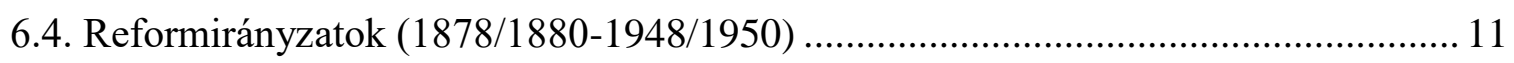

6.5. Az anyagi büntetőjog és tudománya a szocializmus időszakában ........................... 12

6.6. A jogállami büntetőjog tudományának korszaka - gondolatok a büntetőjog és tudományának hazai jelen helyzetéröl …................................................................... 13

7. A büntetőjog tudományának föbb irányai ............................................................... 13

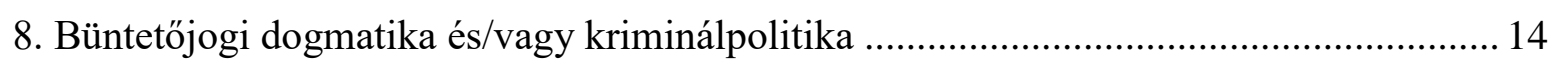

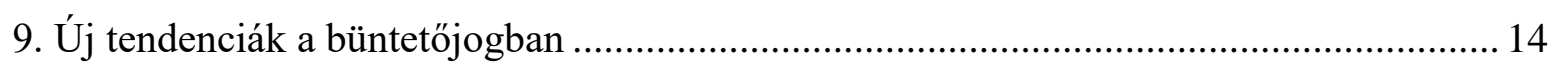

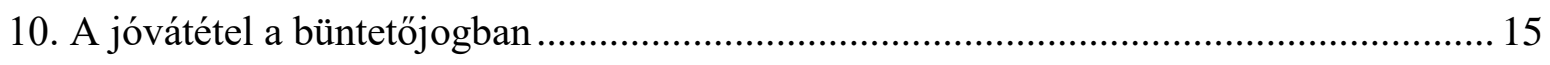

11. Az ellenség-büntetőjogról, a jogállami büntetőjog eróziójáról ..................................... 16

A doktori mű témájához kapcsolódó publikációk (MTMT) …............................................. 18

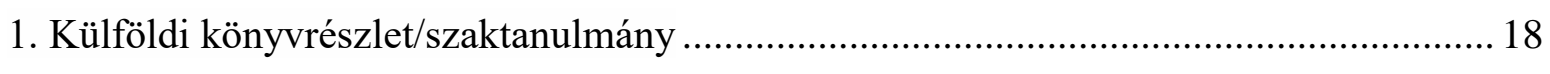

2. Magyar könyvrészlet/szaktanulmány/szakcikk ........................................................ 19 


\section{A KUTATÁSI TÉMA RÖVID ÖSSZEFOGLALÁSA}

A doktori mü témája az anyagi büntetőjog jogágán belül helyezkedik el önálló jogterületi minőséggel. A büntetőjog jelentősebb képviselői közül - a klasszikus büntetőjogi témakörökben kifejtett álláspontjuk kialakítását követően - többen eljutnak a tágabb kontextusban értelmezhető, átfogóbb kérdések vizsgálatához is. Ennek hátterében az állhat, hogy a szakmájukat elméleti igényességgel is müvelő büntetőjogászok számára nehéz kihívás, ugyanakkor talán az aktuális kriminálpolitikai útvesztőből kitörési pont is az elméleti alapkérdések, a büntetőjog tudománytörténetének és jellemző tendenciáinak számbavétele, vizsgálata és tisztázása.

Célkitüzésem a doktori müvel, hogy a büntetőjogot érintő azon elméleti alapkérdésekkel/tendenciákkal foglalkozzam, amelyek a büntetőjog alakulására, fejlődésére meghatározó jelentőséggel bírnak, illetve a saját álláspont kialakításához is segítenek. Így a doktori mủ a kérdéskör elvi megalapozásával, alapvető dilemmáinak felvázolásával kezdődik, majd egy viszonylag széles történelmi tabló áttekintése után napjaink főbb büntetőjogi tendenciái ismerhetők meg. Az elméleti alapkérdések sorában találhatóak az erkölcs/morál és a büntetőjog kapcsolata; a büntetőjog valódi szellemi forrása/gyökere; a szabadság és a biztonság eszméjének (jog)filozófiai háttere és büntetőjogi megjelenése; a büntetőjog feladata; a büntetőjogi dogmatika és a kriminálpolitika jellemzői, egymáshoz való viszonyuk. A büntetőjogot jellemző tendenciák körében külön kiemelésre kerül egyrészt a jóvátétel, a sértetti oldal érdekeinek fokozottabb figyelembevétele, másrészt az ellenség-büntetőjog, a jogállami büntetőjog eróziójának problémaköre.

A doktori mű gerincét adja a hazai anyagi büntetőjog tudományának lényegre törő bemutatása. A hazai büntetőjog-történet előzményeit illetően legelső helyen Finkey Ferenc említhető, aki a tudományterületének (anyagi büntetőjog, büntető eljárási jog, büntetésvégrehajtási jog) korszakos müvekben testet öltő, teljesnek mondható körüljárását követően, annak (jog)történeti vonatkozásait is kutatta. Ennek eredményeként született meg a magyar büntetőperjogi tudomány háromszázados fejlődéstörténetét bemutató műve 1948-ban, amely kéziratban maradt és posztumusz jelent meg 2000-ben Sárospatakon. Finkey ezen alapmunkája mellett a büntetőjog és tudományának története témakörben több hazai kutató is 
jelentős eredményeket ért el, így különösen Bató Szilvia, Békés Imre, Béli Gábor, Györgyi Kálmán, Horváth Tibor, Király Tibor, Mezey Barna, Pauler Tivadar ezirányú munkásságát kell megemlíteni, nevezett szerzők közleményeit a doktori értekezés felhasználja és értékesíti. 


\section{AZ ÉRTEKEZÉS ELKÉSZÍTÉSÉBEN ALKALMAZOTT MÓDSZEREK}

Az értekezés anyagi büntetőjogi témaköre meghatározza az elkészítés során alkalmazott módszereket is, így a tárgyalt büntetőjog-elméleti, tudománytörténeti kérdések és problémák kiválasztása, bemutatása és elemzése során döntően büntetőjogi forrásokra kellett támaszkodni. Az elméleti/dogmatikai kérdéskör általános megközelítéséhez az irányadó idegen/német nyelvű és hazai szakirodalmat, jobbára büntetőjogi és olykor filozófiai szakkönyveket, monográfiákat, valamint szakfolyóiratokban fellelhető tanulmányokat, cikkeket használtam, a történeti, dogmatikai elemzés és jogösszehasonlítás aspektusának figyelembevételével.

A büntetőjog tudománytörténetével összefüggésben az állapítható meg, hogy amennyiben kodifikáció- vagy intézménytörténet vizsgálódásáról van szó, e terület kutatási módszertanának lényege a tényszerüség, a történtek hiteles számbavétele és objektív szemléletü rögzítése. A tudománytörténet azonban nem nélkülözheti az axiológiai, értékelő szemléletet, vagyis bizonyos fokig a szubjektív elemeket is. A tudománytörténet metodikája többnyire nem kodifikáció-történet, és az aktuális jogpolitika, illetve a hatályos tételes jog megközelítési módjától is eltér. Így az elmúlt évtizedek során átfogóbb keretek között fel nem dolgozott anyagi büntetőjog hazai tudományának alakulásáról számol be a szerző hat részre bontott korszakolás alkalmazásával és a meghatározó jogtudósok büntetőjogi munkásságának vázolásával. Továbbá néhány kritikai gondolatot is megfogalmaz a büntetőjog és tudományának jelen helyzetéről. A doktori mű végén, a függelékben kapott helyet a magyar büntetőjog tudományának kiemelkedő alakjairól készített lexikális jellegü összeállítás. 


\section{AZ ÉRTEKEZÉS TUDOMÁNYOS EREDMÉNYEINEK ÖSSZEFOGLALÁSA}

A doktori mű szerzője tizenegy fejezetben kíséri figyelemmel és elemzi a hazai büntetőjog és a büntetőjog-tudomány korábbi és újabb tendenciáit, vagyis fejlődési irányait, tudományos irányzatait.

\section{A büntetőjog morális/erkölcsi eredetéről}

Az első fejezet a messzi régmúltba vezet és a büntetőjog kialakulásának vázlatát és a büntetőjognak az erkölccsel való kapcsolatát igyekszik lényegre törően bemutatni. A szerzői álláspontot ez utóbbi kérdéskörben úgy lehetne összegezni, hogy a büntetőjog és a morál sem nem azonos, sem nem teljesen különböző kategóriák, de közös gyökérre vezethetők vissza. Ha egymást erősítik, ha a büntetőjogi norma erkölcsi támaszt kap, úgy a büntetőjog és annak érvényesítése is hatékonyabb. Ellenkező esetben, ha az erkölcsi elítélés nem segíti, nem erősíti a büntetőjogi rendelkezést, úgy gyengül a büntetőjog érvényesíthetősége és hatékonysága. Nyilvánvaló ugyanis, hogy bizonyos büncselekmények büntetőjogi fenyegetettsége különösebb erkölcsi rosszallással nem kapcsolódik egybe. A fejezet összefoglalásaként rögzíthető, hogy a büntetőjogi norma alkalmazása önmagában és közvetlenül nem hat az erkölcsi tudatra, de közvetve hozzájárulhat az erkölcsi fékek, a morális meggyőződés megerősítéséhez, és az erkölcs támogathatja a büntetőjognak a büncselekmények elkövetésétől visszatartó erejét.

\section{A büntetőjog(-tudomány) szellemi forrásairól}

A második fejezet a büntetőjog közös európai szellemi gyökerét/forrását kutatja. A szerző szerint, bár a büntetőjogon és a büntetőjogi gondolkodáson tetten érhetőek mind a római jog, 
mind a kánonjog hatásai, sőt a büntetőjog közös forrásaiként is értelmezhetők ugyan, de széles körben nem elfogadottak a szakirodalomban. A büntetőjog valódi közös forrása/alapja a (jog)filozófia.

A büntetőjog hazai tudományának egyik fontos, s eddig talán nem kellően hangsúlyozott sajátossága, hogy e jogág elméleti müvelése az idők folyamán más területekhez képest mindig gyakrabban és szorosabban kötődött az észjog, a jogelmélet, a jogbölcselet kérdéseihez. Nem véletlen tehát, hogy számos neves büntetőjogász - miként például Vuchetichtől, Paulertől, Finkeyn, Angyalon át Losoncziig - jogfilozófiával is elmélyülten foglalkozott.

\section{A szabadság és a biztonság (jog)filozófiai hátteréről}

A felvilágosodás időszakából (is) lényegi kérdés - egyúttal büntetőjogi alapprobléma -, a szabadság és/vagy biztonság (jog)filozófiai hátterét világítja meg ez a fejezet és jut el a szerző a jelenkori alkotmányossági és büntető elvi vetületéhez. A szinte egészében elméleti/történeti jelentőségű fejezetet - amelyben a szerző többek között az ún. társadalmi szerződések kérdéseit dolgozza fel - át- és átszövik a jelenkori büntetőjogi gondolkodásra való utalások, áthallások. A szerző nézete szerint a jogállami büntetőjog megalapozásának élén állnak a szabadság, a (jog)biztonság, az emberi méltóság és az univerzális emberi jogok. Ezek az új társadalmi szerződés központi ismérvei.

A büntetőjog az állami biztonsági érdekeknek nem lehet mindenható eszköze és kiszolgálója, hanem a polgárokat védelmezi az állami beavatkozásoktól a szabadság és az emberi méltóság lényeges terrénumain. Az alapelvek a szabadság, az emberi méltóság, a (jog)biztonság védő, óvó formái, amelyeket a büntetőjogba és a büntetőeljárási jogba kell átültetni. Az ilyen értelemben vett szabad, legitimált büntetőjog nevezhető jogállami büntetőjognak.

\section{A büntetőjog feladatáról}

A negyedik fejezet a büntetőjog feladataival foglalkozik, és a szerző részletesen bemutatja a kérdés német és magyar szakirodalmát. A szerző felfogásában a büntetőjog feladata ellenvetés nélküli monista konstrukcióba nem illeszthető be, hanem csak azáltal magyarázható 
értelmesen, hogy az általános és a különös feladatok a büntetőjog egymást feltételezö, azonos értékü, kölcsönösen kiegészitö és korlátozó funkciójaként értendök. Tehát a büntetöjognak nem lehet egyedüli célja.

A büntetőjog általános feladatát illetően a büntetőjog mindenekelőtt védelmi jog, azaz a közösségi lét elementáris, fontos érdekeinek, alapjainak biztosítása a nemzetközileg elismert emberi jogok figyelembevételével. A közösségi együttélés alapvető értékei/érdekei a büntetőjogi védelembe vonásukkal jogi tárgyakká válnak. A jogtárgyvédelem, amely napjainkra hazánk és a német büntetőjogi elméletben és gyakorlatában is az egyik legföbb büntetőjogi funkcióvá lépett elő - nem tekinthető a büntetőjog egyetlen feladatának. Ugyanis a puszta jogtárgyvédelem negatív - megelőző rendőri - preventív céltételezés. A büntetőjog legmélyebb feladata pozitív szociáletikai természetü. A szerző szerint is a jogtárgyvédelem elvét átfogóbb és nagyobb társadalmi összefüggésbe kell ágyazni, így a büntetőjog feladata az elementáris szociáletikai értékek védelme, s ebben és ezáltal kaphat helyet a jogi tárgyak védelme. A büntetőjognak továbbá nemcsak a jogi tárgyakat sértő vagy veszélyeztető magatartások elleni fellépés a feladata, hanem az állampolgárok jogkövető magatartásának az elősegítése is. A büntetőjognak azonban nem lehet kizárólagos feladata a jogi normák orientáló funkciójának garantálása sem. Ez a feladat-meghatározás önmagában ugyanis tágra, túlzottan szélesre nyitná/nyithatná a büntetőjogi beavatkozás lehetőségét, ami alkotmányos jogállamban nem megengedhető.

\section{A magyar büntetőjog tudományáról - a (büntetőjog)tudomány ismérveiről, hazai előzményeiről és kezdeteiről}

Logikailag, kronológiailag és tartalmilag összeolvad az ötödik és a hatodik fejezet. Különkezelésük lényegében azon alapszik, hogy a XIX. századot megelőző időszakban éles, illetve egyértelmü elkülönítés még nem volt tehető a büntető anyagi és eljárási jog között. Ezért míg az ötödik fejezet mind az anyagi, mind az eljárási jog történetével foglalkozik a büntetőjog-tudomány ismérvei és hazai előzményei mellett, addig a hatodik - amely már arról a későbbi időszakról szól, amikor a kettő már elkülönült - már csak az anyagi büntetőjog tudományának történetét tartalmazza. A tudomány ismérvei körében a kiindulópontot Kant jelenti, aki szerint minden tan, ha az rendszer, tudománynak nevezi magát. Anselm von 
Feuerbach viszont nyomatékosan hangoztatta a büntetőjog-tudománynak az empirikusan adott joganyaghoz való kötöttségét. A legelső valóban tudományos értékű tan-/kézikönyv hazai szerzőjének megfogalmazásában: [...] a képződményt, amelyben a magyar büntetőtörvények helyes ismeretét, értelmezését, valamint az arra vonatkozó tényezők nemeit és a megfelelő alkalmazás rendjét bemutatják, magyar büntetőjog-tudománynak mondják." Vagyis Vuchetich a büntetőjog tudományának meghatározásánál nem a kanti értelemben vett rendszert emelte ki és helyezte előtérbe, hanem a feuerbachi gondolatnak megfelelően az empirikusan adott joganyaghoz, azaz a magyar büntetőtörvényekhez való kötöttséget.

A XIX. század utolsó évtizedeinek magyar jogfejlődésében már egyértelművé vált a rendszerszemlélet, a „rendszer” iránti igény, amely nélkül „tudomány, különösen jogtudomány nincs”. Ez a felfogás jelenleg is képviselt és elfogadott, vagyis a szerző szerint is a büntetőjog-tudomány a büntetöjogra vonatkozó ismeretek és nézetek rendszerét jelenti.

A büntetőjog és a büntetőeljárás tudományának hazai kezdeteit (1742-1751) illetően a magyar büntetőjog jogforrási rendszerének és így a tudományának speciális sajátossága az 1880. szeptemberig tartó időszakban az egységes törvényi szabályozás hiánya. Rövidebb periódusoktól eltekintve (1787-1790, 1852-1860) a szokásjog volt az uralkodó jogforrás.

A kodifikációs kísérletek eredménytelenül zárultak az 1878. évi büntető kódexig. Emiatt a magyar büntetőjog jellemző ismérvei nem a törvényekből, ezek magyarázataiból, hanem legfeljebb a bírósági gyakorlatból rekonstruálhatók.

A kodifikációs nehézségek következtében a magyar büntetőjogi szakirodalom viszonylag későn alakult ki: az első büntetőjogi művek a XVIII. század közepén jelentek meg, azonban rendszeres publikációs tevékenységgel a XIX. század 30-as évei óta lehet csak számolni. Ezért a fejletlen magyar büntetőjogi szakirodalomnak más volt a szerepe, ugyanis a kézikönyvek (szerzői) nem a hatályos magyar büntetőjogot kommentálták, hanem lényegében pótolták a hiányzó törvényeket. A szerzők a modern büntetőjogi elveket és jogállami követelményeket a magyar valósággal kísérelték meg összhangba hozni. A magyar múlt büntetőjog-tudományának/dogmatikájának kutatásához két előfeltétel szükséges. Az egyik a törvénytervezetek önálló általános részének léte, továbbá a büntetőjog-tudományban az anyagi jognak az eljárásjogtól történő végleges szétválasztása. A magyar büntetőjogi fejlődés során ezek az előfeltételek viszonylag későn alakultak ki, ezért a büntetőjogi dogmatika elemei/ismérvei (pl. büncselekmény-fogalom) a XIX. század közepe előtt az egyes büncselekmények fogalmi elemzése révén rekonstruálhatók. 
A magyar büntetőjogi irodalomban a XVIII. század második feléig a processzuális szemlélet uralkodott, ezért a korabeli szerzők az anyagi jog legfontosabb általános fogalmairól (pl. dolus, culpa, büntetési nemek) műveik büntetőeljárási szabályai között írtak.

A kezdeti korszak négy tudományos képviselője - Huszti András, Gochetz Gábor, Huszty István, Bodó Mátyás - közül Huszty István és Bodó Mátyás rendszerező munkáit lehet kiemelni a korszak jelentősebb büntetőjogi munkáiként. Huszty és Bodó műve is nagy hatást gyakorolt a jogászképzésre és a bírói gyakorlatra egyaránt. A müveik abban egységesek voltak, hogy alapvetően a processzuális megközelítést alkalmazták, ahol az eljárási jog még nem vált el a büntető anyagi jogtól. További közös vonás - az akkoriban természetesnek tekintett latin nyelv használata mellett - Carpzov, a XVII. századi lipcsei büntetőjogász 1635. évi fő müve hatásának továbbélése.

\section{Az anyagi büntetőjog tudományáról hazánkban}

A kodifikáció- vagy intézménytörténet módszertanának lényege a tényszerüség, a történtek hiteles számbavétele és objektív szemléletü rögzítése. A tudománytörténet azonban nem nélkülözheti az axiológiai, értékelő szemléletet, vagyis a szubjektív elemeket. A magyarországi anyagi büntetőjog tudományának lényegre törö bemutatásánál a büntetőjog tudományának hazai kezdeteit követően a következő korszakolást alkalmazzuk:

- $\quad$ A korai büntetőjogi kodifikációs kísérletek időszaka (1790-1848);

- $\quad$ Az abszolutizmus korszaka (1848/1852-1860/1867);

- $\quad$ A klasszikus kodifikáció időszaka (1867-1878);

- $\quad$ Reformirányzatok a büntetőjogi irodalomban és a büntető jogalkotásban (1878/18801948/1950);

- $\quad$ Az anyagi büntetőjog tudománya a szocializmus korszakában (1948/1950-1989);

- A rendszerváltozással kezdődő és jelenleg is tartó ún. modern/posztmodern jogállami büntetőjog tudományának korszaka, azaz az anyagi büntetőjog tudománya 1989 után.

\subsection{A korai büntetőjogi kodifikációs kísérletek időszaka (1790-1848)}


A büntető(jog)-tudomány kezdeti sikertelen törvényalkotási sorozata, erre a korszakra is jellemző. Ebben az időszakban a büntetőjog és a büntetőeljárás tudományának fejlődését a kiváló tehetségü jogtudósok mellett a reformkori politikusok és munkáik is elősegítették. A jogtudósok közül a legjelentősebbek Szlemenics Pál, Vuchetich Mátyás, Szalay László, Szokolay István voltak. Közülük az első valóban tudományos igényü és értékü büntetőjogi tan- és kézikönyvet Vuchetich Mátyás készítette 1819-ben. Ebben a munkában Vuchetich az új felvilágosult, humánus büntetőjogi eszmeiséget érvényesítve kísérletet tett a hazai joggyakorlat és a felvilágosodás föbb tételeinek az összeegyeztetésére.

Erre a korszakra már jellemző a büntetőjog fokozatos modernizálása is, a megalázó testi büntetések és a halálbüntetés helytelenítése azonban még csak kivételes. A halálbüntetés kapcsán kivételként említhető a korszakból Szemere Bertalannak e büntetési nemet ellenző felfogása.

\subsection{Az abszolutizmus korszaka (1848/1852-1860/1867)}

Az abszolutizmus ,jogfosztott” időszakában egyedül Csatskó Imre munkásságát lehet kiemelni. Az első nagyobb büntetőjogi munkájában a külföldi büntetési elméleteket tekintette át és mutatta be. Csatskó az akkoriban Magyarországon is alkalmazni rendelt osztrák büntető kódexről is kommentárt készített.

\subsection{A klasszikus kodifikáció időszaka (1867-1878)}

A klasszikus kodifikáció időszakát két nagyobb alkorszakra lehet bontani. Az egyik a szakirodalomban a Pauler Tivadar nevével fémjelzett átmeneti időszak, a másik pedig a Csemegi Károly és Fayer László által képviselt valódi kodifikációs korszak.

Pauler Tivadar legnagyobb jelentőségü műve az első ízben 1864-ben kiadott Büntetőjogtan c. könyve, amely tudományos jellegü tankönyv volt, de külsőleg egy valódi kódex képét mutatta. A rövid idő alatt három kiadást megért tankönyv olyan kiválónak minősült, hogy az egyetemeken, jogakadémiákon ebböl oktattak; a gyakorlatban pedig a bíróságok csaknem törvénykönyvként használták.

Csemegi Károly kiváló tehetségét tükrözi, hogy mind az anyagi jog, mind az eljárásjogi kodifikációs tevékenységben aktívan részt vett. Amíg a büntető anyagi jog javaslatai 
rendkívül sikeresek voltak, addig az eljárásjog területén kevésbé volt szerencsés. Vagyis „Csemegi Károlyé az érdem, hogy Magyarországon az anyagi büntetőjog kodifikálva van.” (Fayer) A kódex általános része 70 évig volt hatályban és mély nyomokat hagyott a magyar büntetőjogi gondolkodásban.

Fayer László tudományos munkássága egyértelmüen a büntető anyagi jog és a bünvádi eljárási jog reformjának megalapozására és ezzel kapcsolatban az igazságszolgáltatási szervezet megújítására irányult. Nem a jogi dogmatika kérdései érdekelték elsősorban, hanem inkább az emberiességi szempontok, az alkotmányjogi vonatkozások, a büntetési rendszer kérdései.

Vitathatatlan Csemegi és Fayer szerepe a korszakban, azonban rajtuk kívül más neves büntető jogtudósok is alkottak a XIX. század utolsó negyedében és a századforduló körüli időszakban. Közülük Edvi Illés Károly, Wlassics Gyula és Baumgarten Izidor munkássága tekinthető jelentősnek.

\subsection{Reformirányzatok (1878/1880-1948/1950)}

A reformirányzatok periódusban a büntetőjoggal kapcsolatos elméleti, irodalmi tevékenység valójában két fö - de mereven nem elkülöníthető - periódusban vizsgálható. Az első periódusban az első világháború időszakáig a büntetőjogi reformirányzatok szellemi kisugárzása, a kriminológiai szemlélet térhódítása a jellemző. A századforduló idején elsősorban Balogh Jenő érdeme a modern büntetőjogi, kriminológiai tanok magyarországi befogadásának és tételes joggá válásának szorgalmazása. A kriminálpolitikai célgondolat legerősebben Vámbéry Rusztem és Irk Albert műveiben jelentkezett, akik az elsők között végzik el a büntetőjogi szankciók, intézkedések átfogó elméleti feldolgozását is hazánkban. A második periódusban az első világháborút követő évtizedekben a társadalomvédelmi szempontok kerülnek előtérbe. A szankciórendszer radikális átépítése helyett a közvetítő irányzat kapott mindinkább domináns szerepet. Az egyoldalúság helyett a gyakorlatiasság és a rugalmasság igényei kerültek előtérbe.

A világháborút követően eredeti, önálló elméleti gondolatok kifejtése, a kriminológiai kutatások folytatása helyett jobbára a fennálló nézetek mértéktartó egyeztetésére és logikai összefoglalására törekedtek. Ennek az utóbb említett összefoglalásnak legkiválóbb képviselője Finkey Ferenc volt. Finkey mellett a korszak tárgyalása ezen időszak további 
meghatározó, kiemelkedő tudományos képviselőinek (Angyal, Heller, Irk, Hacker) bemutatásával folytatódik.

A század első felében a legszínvonalasabb munkák közé tartoztak a tankönyvek. E tekintetben mind Vámbéry, Finkey, Angyal, mind Irk, Heller, Hacker tankönyvei kiemelkedő szintetizáló müveknek tekintendők. A világháborút követő időszakban, főként a 30-as évektől korlátozott mértékben a tettes-büntetőjogi irányzat, a veszélyességre épülő kriminálpolitikai szemlélet erősödött, és problematikus jogintézmények, tételes jogi megoldások, illetve aggályos elméleti állásfoglalások születéséhez, létrejöttéhez is vezetett.

\subsection{Az anyagi büntetöjog és tudománya a szocializmus időszakában}

A szocializmus időszakában megállapítható, hogy az 1940-es évtized végétől kezdődően a büntetőjog szerepének átértékelése és a kriminálpolitika új arculata jelent meg. A büntetőjog elveszítette garanciális funkcióját a hatalom korlátozását és az egyén jogait védő szerepét. A büntetőjog tudománya, a dogmatika leértékelődött, jogászi szőrszálhasogatássá vált. A kriminálpolitikából a politika kriminalizálása alakult ki, amely egy döntően paternalista jogpolitika térnyeréséhez vezetett. A szocializmus időszakát a társadalom ,agyonpolitizálása” és az egységes marxista ideológia jellemezte. Új alapokra épült a bűncselekménynek a dogmatikai struktúrája is. A büncselekménnyé nyilvánítás új legitimációs forrását a társadalomra veszélyesség fogalmi kategóriája szolgáltatta. Az 1950-es években és a '60-as évek első felében a magyar büntetőjog tudománya leszakad a korábban irányadó német tudományról. Az 1950-es évek vége felé azonban már „felbukkannak” német szerzők a magyar szakirodalomban. Az 1960-as évek végétől az NSZK büntetőjog-tudománya reprezentánsaira hivatkozás nélkül már elképzelhetetlen volt Magyarországon a büntetőjog tudományos müvelése és monográfiák megjelentetése. A korabeli ideológiától - legalábbis részben - függetlenítve jelentős és korszakos munkák születtek, ezt mutatják Szabó András, Viski László, Földvári József, Horváth Tibor, Tokaji Géza, Békés Imre, Györgyi Kálmán, Nagy Ferenc ezidőtájt született művei. Az 1970-es évtized második felétől, az 1980-as évtizedtől az anyagi büntetőjog mellett a büntetéstani, a büntetés-végrehajtási jog és a kriminálpolitika területén is az adott évtizedet/korszakot meghatározó könyvek jelentek meg (Horváth Tibor, Földvári József). 


\subsection{A jogállami büntetőjog tudományának korszaka-gondolatok a büntetőjog és} tudományának hazai jelen helyzetéröl

A büntetőjog tudománya művelésében alapvetően meghatározó körülmény az, hogy Magyarországon nincs szerves, egymásra épülően felfelé ívelő fejlődés. Ezt a fejlődési folyamatot ugyanis meg-megszakították a különböző ideológiai hátterű események, történések.

A büntetőjog hazai tudománya igen fontos, s talán nem kellően hangsúlyozott sajátossága, hogy e jogterület elméleti művelése az idők folyamán vissza-visszatérően erősen és szorosan kötődött az észjog, a jogelmélet, jogbölcselet kérdéseihez.

A büntetőjognak jogállami alapokra helyezését követően jelenleg a büntetőjog tudománya, a büntetőjogi dogmatika (át)kriminálpolitizálódott, vagyis a kriminálpolitika a hatókörét kiterjesztette, a büntetőjogi dogmatikára is rátelepedett. Az alkotmánybíráskodás hatásának hazai növekedésével, illetve változásával kapcsolatban pedig a bíráskodásban a jogdogmatikai kötöttség viszonylag csekély fokú és jobban előtérbe kerülnek az absztraktan megfogalmazott, illetve priméren etikai-társadalmi mérlegelési szempontok. A jogdogmatika leértékelődik és egy átpolitizáltabb jogászi tevékenység válik mintaértéküvé.

A büntetőjog tudománya elért eredményeinek bemutatását követően röviden említést kell tenni a büntetőjog tudományos müvelését hátráltató hazai tényezőkről, sajátosságokról:

Jellemző hazai sajátosság a magyar büntetőjog tudományában az alapkutatások elhanyagolása, elmaradása. A fiatalokat feltehetőleg nem ösztönözheti a hosszadalmasabb alapkutatások végzésére a gyors előmenetelhez szükséges „,publikációs kényszer”. Egy-egy témakör sokoldalú, átfogó feldolgozását tartalmazó monográfiák korszaka - úgy tünik leáldozóban van. A jogi szakkönyveket megjelentető kiadók anyagilag egyáltalán nem érdekeltek a monográfiák közzétételében, legfeljebb a több száz példány eladása reményében többnyire tananyagok, kommentárok kerülnek publikálásra. Az angol nyelv egyeduralmával a fiatal tudományos generáció nagy része az angolon kívül a német nyelvet nem ismeri, márpedig az anyagi büntetőjog szaknyelve változatlanul a német.

\section{A büntetőjog tudományának főbb irányai}


A hetedik fejezet a büntetőjog tudományos irányzatai keretében először a klasszikus büntetőjogi iskola meghatározó felvilágosodás-korabeli képviselöjének, Beccaria büntetőjogi vonatkozású alapmüvét mutatja be, és értékeli egyrészt a hagyományos dicsérően értékelő Beccaria-recepciójáért, másrészt a Naucke-féle leértékelő Beccaria-sémára figyelemmel. A doktori mű szerzője ezt követően foglalkozik a pozitivista, továbbá a szintézisre törekvő közvetítő irányzattal. Az újabb társadalomvédelmi és alternatív büntetőjogi irányzatok bemutatása is helyet kap a fejezetben. Ezzel kapcsolatban a szerző erőteljes kritikát fogalmaz meg az USA-ból eredő és terjedő ún. kemény kéz büntetőpolitikájával szemben. Ez a döntően az elrettentésre épülő „law and order” kriminálpolitika tartós sikert nem eredményezhet és a figyelmet rossz irányba tereli. Ugyanis azt a téves képzetet és félreértést keltheti, illetve erősítheti, hogy a büntető szabályok és az ítélkezés szigorításával már önmagában a nemkívánatos társadalmi jelenségek, feszültségek oldását és megoldását lehetne elérni.

\section{Büntetőjogi dogmatika és/vagy kriminálpolitika}

Ez a fejezet a büntetőjogi dogmatikára vonatkozó fogalmi jegyeket, hazai és német különböző nézeteket mutatja be. A büntetőjogi dogmatika a szerző álláspontja értelmében nem csupán a büntetőjog tudományának módszere, hanem maga is tudományág, tan, amely különböző módszerek segítségével illeszti a hatályos jogot fogalmi, elméleti rendszerbe. A fejezet a dogmatika és a kriminálpolitika egymáshoz való viszonyát is érinti. Ezt a szerző a jelenkorban úgy jellemzi, hogy a büntetőjogi dogmatika (át)kriminálpolitizálódott lett, vagyis a büntetőjogi dogmatika lényegében a (kriminál)politika eszközévé, szolgálójává süllyesztett és silányított lett. Ilyen válságos időkben pedig nem, illetve nemigen köthető kompromisszum a világos és koherens jogállami garanciális elvek és az ezeket lépten-nyomon felülírni kívánó jogpolitika és joggyakorlat igényei között. Az aggályos helyzet jobbítására vonatkozó javaslatát a szerző elsősorban a bủnügyi tudományok művelőihez címzi, akiknek a nem jogállami célkövetés erőteljes kritikájára kell törekedni.

\section{9. Új tendenciák a büntetőjogban}


A büntetőjogban kirajzolódó új tendenciákat tekinti át és mutatja be a kilencedik fejezet. Az első témakör a büntetendőség/büntethetőség kiterjesztése (németül: Vorverlagerung), amely alatt a jogalkotó azon eljárását lehet érteni, amikor a klasszikus bủncselekmények elkövetésének virtuális idősíkján előbbre helyezi/kiterjeszti a büntetendőséget. Ez a kiterjesztés horizontális és/vagy vertikális síkon egyaránt történhet. Továbbá tényállásértelmezéssel és új tényállásalkotással is megvalósulhat.

Hazai szakirodalomban újdonság az elsőként a szerző által nevesített szimbolikus büntetőjog problémaköre. Ennek jellemzője, hogy esetében a törvényhozó (csak) azt a célkitüzést követi, hogy felhívja a figyelmet a közvéleményben a gondos és dönteni képes jogalkotásra, azonban a valódi problémát meg sem próbálja orvosolni, a problémakezelés kimerül a szimbolikus jellegű büntetőjogi szankció(k) előírásában. A szimbolikus büntetőjog kitétel és szerzői fogalomhasználat találó a legutóbbi idők hazai büntetőjogának jellemzésére is.

A büntetőjogban olyan modern tendenciák is megfigyelhetők, amelyek egyre inkább elvonják a joggyakorlat figyelmét a szabadság védelméröl, a szabadság és a biztonság közötti harc súlypontja eltolódik és máshová kerül. Azonban a szabadságjogoknak mindig is józan korlátot kell szabniuk az állam biztonságigénye számára.

\section{A jóvátétel a büntetőjogban}

A jóvátétel, a büncselekmény áldozatainak segítése és védelme áll világszerte a jelenlegi kriminálpolitikai viták középpontjában. Vagyis napjainkban nemcsak az angolszász, hanem a kontinentális jogrendszerekben is az áldozatcentrikus felfogás, a helyreállító igazságszolgáltatás (restorative justice) térnyerése figyelhető meg, amely a jóvátétel mind differenciáltabb formáinak bevezetésében és alkalmazásában is testet ölt. A történeti aspektusok és a jóvátételi modellek felvázolása után a tizedik fejezet a jóvátétel lehetséges büntetőjogi normáit tekinti át és mutatja be. Elsősorban az anyagi büntetőjog területére eső jóvátételi változatokra koncentrál, azonban a szerző ehelyütt szól a büntetőeljárási szabályok alapján érvényesülő jóvátételi formákról is. Az anyagi büntetőjogban érvényesülő jóvátételi változatok között a jóvátétel jogintézménye lehet:

büntethetőségi akadály (megszüntető ok); 
- Önálló szankcióforma büntetés vagy intézkedés, avagy sui generis „harmadik nyomú” szankció formájában;

- $\quad$ szankciószurrogátum;

- $\quad$ büntetéskiszabási körülmény.

A jóvátételnek immateriális, szimbolikus formái is léteznek, sőt a büntetés-végrehajtás keretében szintén helyet kaphat.

\section{Az ellenség-büntetőjogról, a jogállami büntetőjog eróziójáról}

Az utolsó fejezet a magyar szakirodalomban kevéssé ismert témakört, az ellenség-büntetőjog kérdését dolgozza fel. A szervezett bünözés és a terrorizmus elleni hatékony küzdelem elméleti megalapozását és büntetőjogi körülbástyázását célul kitűző teória szerint a büntetőjogon belül különbséget kell(ene) tenni egyrészt polgár-, másrészt ellenség-büntetőjog között. Míg a polgár-büntetőjog esetében az elkövető a büntetőeljárás alanya, akit garanciális rendelkezések védenek, addig az ellenség-büntetöjogban a vádlott olyan potenciális veszélyforrás, akit mint az eljárás puszta tárgyát jogok nem illetik meg, és akivel szemben - a társadalmi biztonság érdekében - akár elkövetett cselekmény hiányában is, prognózisok alapján is fel lehet és fel kell lépni.

A szerző értékelése szerint a polgár- és ellenség-büntetőjog közötti különbségtétel visszatérő kísérő jelensége a büntetőjognak, továbbá a büntetőjog alapelvei meginogni látszanak, és fennáll az a veszélyes lehetőség, hogy a jogállam helyébe a biztonsági állam és biztonsági büntetőjog lép. Az ellenség-büntetőjogról alkotott végső véleménye egyértelmüen elutasító: meghatározott személycsoportok - akár terroristák vagy más veszélyes büntettesek - személyi státuszának tagadása számos centrális jelentőségü alkotmányos elvbe ütközne, így a jogállamiság elvébe, az emberi méltóság követelményébe, a tettfelelősség elvébe, a bűnösségi elvbe, az ártatlan védelmébe, a törvény előtti egyenlőség követelményébe. Ehhez még nagy visszaélési veszély is társulna. Hiszen hogy ki az ellenség, azt a mindenkori törvényhozó hatalom definiálná.

A doktori mü a magyar büntetőjog-tudomány kiemelkedő alakjainak lexikális jellegü életrajzával zárul. Ebben a függelékben a büntetőjog klasszikusai mellett a közelmúltban 

Szabó András, Wiener A. Imre) életútjának rövid bemutatása is helyet kapott.

elhunyt több neves büntetőjogász professzor (így Békés Imre, Erdösy Emil, Földvári József, 


\section{A DOKTORI MÜ TÉMÁJÁHOZ KAPCSOLÓDÓ PUBLIKÁCIÓK (MTMT)}

\section{Külföldi könyvrészlet/szaktanulmány}

Überblick über die Entwicklung des ungarischen Strafrechts von 1948 bis 1950 bzv. von 1950 bis 2010. In: Arndt Sinn - Walter Gropp - Ferenc Nagy (szerk.): Grenzen der Vorverlagerung in einem Tatstrafrecht: Eine rechtsvergleichende Analyse am Beispiel des deutschen und ungarischen Strafrechts. Universitätsverlag, Osnabrück, 2011.

( Schriften des Zentrums für Europäische und Internationale Strafrechtsstudien; Bd. 1. )

Krisztina Karsai - Ferenc Nagy - Zsolt Szomora (szerk.): Freiheit - Sicherheit - (Straf)Recht: Beiträge eines Humboldt-Kollegs. Universitätsverlag Rasch, Osnabrück, 2011.

( Schriften des Zentrums für Europäische und Internationale Strafrechtsstudien; 2. )

Tatstrafrecht und Täterstrafrecht. In: Arndt Sinn - Walter Gropp - Ferenc Nagy (szerk.): Grenzen der Vorverlagerung in einem Tatstrafrecht: Eine rechtsvergleichende Analyse am Beispiel des deutschen und ungarischen Strafrechts. Universitätsverlag, Osnabrück, 2011. 65-87. p.

( Schriften des Zentrums für Europäische und Internationale Strafrechtsstudien; Bd. 1. )

Exkludierende/isolierende Elemente im ungarischen Strafrecht. In: Krisztina Karsai - Ferenc Nagy - Zsolt Szomora (szerk.): Freiheit - Sicherheit - (Straf)Recht: Beiträge eines HumboldtKollegs. Universitätsverlag Rasch, Osnabrück, 2011. 175-187. p.

( Schriften des Zentrums für Europäische und Internationale Strafrechtsstudien; 2. )

(Trans)Formation of Substantive Penal Law since the Political Transformation in Hungary In: Vanda Lamm (szerk.): Transformation in Hungarian law, 1989-2006: selected studies. Akadémiai Kiadó, Budapest, 2007. 175-208. p. 


\section{Magyar könyvrészlet/szaktanulmány/szakcikk}

A büntetőjog tudománya. In: Jakab András - Menyhárd Attila (szerk.): A jog tudománya: Tudománytörténeti és tudományelméleti írások, gyakorlati tanácsokkal. Budapest: HVGORAC Lap- és Könyvkiadó Kft., Budapest, 2015. 261-333. p.

A büntetőjog feladatáról - német és magyar szakirodalmi áttekintés alapján. In: Nagy Csongor István (szerk.): Liber Amicorum János Martonyi. Ünnepi kötet Martonyi János tiszteletére. Festschrift für János Martonyi. Mélanges en l'honneur du János Martonyi . HVGORAC, Budapest, 2014. 317-326. p.

Új tendenciák a büntetőjogban. In: Borbíró Andrea - Inzelt Éva - Kerezsi Klára - Lévay Miklós - Podoletz Léna (szerk.): A büntető hatalom korlátainak megtartása: A büntetés mint végső eszköz : Tanulmányok Gönczöl Katalin tiszteletére. ELTE - Eötvös Kiadó, Budapest, 2014. 361-370. p.

Új tendenciák a büntetőjogban. In: Pál József - Vajda Zoltán (szerk.): Bölcsészet- és társadalomtudományok. Szegedi Egyetemi Kiadó, Szeged, 2014. 56-67. p.

( Szegedi Egyetemi Tudástár; 7. )

A szegedi büntetőjogi/dogmatikai iskola meghatározó képviselőiről. In: Hajdú József (szerk.): 90 éves a szegedi jogászképzés. Szegedi Tudományegyetem Állam- és Jogtudományi Kar, Szeged, 2013. 133-149. p.

A büntetőjogi dogmatikáról Békés Imre műveiben. In: Gellér Balázs - Csige Zoltán (szerk.): Békés Imre emlékkötet. Tullius Kiadó, Budapest, 2013. 155-163. p.

A (büntetőjog)tudomány ismérveiröl, hazai előzményeiröl és kezdeteiröl. In: Juhász Zsuzsanna - Nagy Ferenc - Fantoly Zsanett (szerk.): Sapienti sat: Ünnepi Kötet Dr. Cséka Ervin professzor 90. születésnapjára. Szegedi Tudományegyetem Állam- és Jogtudományi Kar, Szeged, 2012. 353-363. p. 
Büntető jog és tudománytörténeti előzmények és kezdetek Magyarországon. In: Gál István László (szerk.): Tanulmányok Tóth Mihály professzor 60. születésnapja tiszteletére.

Pécsi Tudományegyetem, Állam- és Jogtudományi Kar, Pécs, 2011. 423-430. p.

A magyar anyagi büntetőjog (át)alakulása a rendszerváltozás óta. In: Lamm Vanda (szerk.): Rendszerváltás a jogban. MTA JTI - MTA TK, Budapest, 2009. 171-206. p.

Büntetőjogi dogmatika és/vagy kriminálpolitika. In: Nagy Ferenc (szerk.): Tudományos előadóülés a Bünügyi Oktatók Országos Találkozóján: Szeged, 2009. június 5.

Szegedi Tudományegyetem Állam- és Jogtudományi Kar, Szeged, 2009. 9-19. p.

Kriminálpolitikai gondolatok magyar és nemzetközi kitekintéssel. In: Csemáné Váradi Erika (szerk.): Koncepciók és megvalósulások a rendszerváltozás utáni kriminálpolitikában: VI. Országos Kriminológiai Vándorgyülés - Miskolc, 2008. október 16-17. Bíbor Kiadó, Miskolc, 2009. 37-43. p.

( Kriminológiai Közlemények, Különkiadás )

Az ellenség-büntetőjogról, a jogállami büntetőjog eróziójáról. In: Nagy Ferenc (szerk.): Ad futuram memoriam: tanulmányok Cséka Ervin 85. születésnapja tiszteletére. Pólay Elemér Alapítvány, Szeged, 2007. 244-259. p.

A magyar anyagi büntetőjog (át)alakulása a rendszerváltozás óta. In: Jakab András - Takács Péter (szerk.): A magyar jogrendszer átalakulása, 1985/1990 - 2005: Jog, rendszerváltozás, EU-csatlakozás. Gondolat; ELTE ÁJK, Budapest, 2007. 431-463. p.

Helyzetkép-vázlat a büntetőjogi dogmatikáról. In: Szabó Miklós (szerk.): Jogdogmatika és jogelmélet. Bíbor Kiadó, Budapest, 2007. 273-290. p.

Vázlat a büntetőjogi dogmatikáról. In: Szabó Imre - Tóth Károly (szerk.): Tanulmányok Dr. Besenyei Lajos egyetemi tanár 70. születésnapjára. Szegedi Tudományegyetem, Szeged, 2007. 537-555. p. 
The development of the hungarian criminal law over the past twenty years. (társszerzö: Szomora Zsolt). In: Jakab András - Takács Péter - Tatham Allan F (szerk.): The transformation of the Hungarian legal order 1985-2005: transition to the rule of law and accession to the European Union . Kluwer Law International, Alphen aan den Rijn, 2007. 191-206. p.

A büntetőjog legújabb változásairól - nemzetközi és hazai kitekintés alapján. In: Tóth Károly (szerk.): Emlékkönyv Dr. Szabó András 70. születésnapjára. JATE Állam- és Jogtudományi Kar, Szeged, 1998. 251-264. p.

A büntetőjog legújabb változásairól - nemzetközi kitekintés alapján. In: Gönczöl Katalin Kerezsi Klára (szerk.): Tanulmányok Szabó András 70. születésnapjára.

Magyar Kriminológiai Társaság, Budapest, 1998. 191-201.p.

Új fejlődési irányok, avagy a tradicionális jogállami büntetőjog eróziója. In: Irk Ferenc (szerk.): A bünözés jövője: Emlékkönyv Pusztai László tiszteletére halála első évfordulóján. Országos Kriminológiai Intézet, Budapest, 1997. 53-62. p.

Változási tendenciák és ellentmondások a büntetőjogban. In: Farkas Ákos - Görgényi Ilona Lévai Miklós (szerk.): Horváth Tibor professzor 70. születésnapjára. Bíbor Kiadó, Budapest, 1997. 76-90. p.

Jóvátétel mint a konfliktusfeloldó büntető igazságszolgáltatás egyik formája. In: Gönczöl Katalin - Kerezsi Klára (szerk.): Büntetőpolitika, bünmegelőzés: tanulmánygyüjtemény a szociális szakképzés számára. ELTE Szociológiai Intézet, Budapest, 1994. 48-73. p.

A büncselekmény áldozatának állami kártalanításáról. In: Tóth Károly (szerk.): Emlékkönyv Dr. Kemenes Béla egyetemi tanár 65. születésnapjára. JATE, Szeged, 1993. 287-298. p.

Az ellenség-büntetőjogról, a jogállami büntetőjog eróziójáról. Magyar Jog 2007/2. 65-75. p.

Helyzetkép-vázlat a büntetőjogi dogmatikáról. Magyar Jog 2007/5. 273-282. p. 
Az ellenség-büntetőjogról, a jogállami büntetőjog eróziójáról. Acta Universitatis Szegediensis de Attila József Nominatae Sectio Juridica et Politica 2006/17. 1-21. p.

Európai kihívások, magyar válaszok a büntetőjog és a büntetés-végrehajtás területén. Börtönügyi Szemle 2003/1. 13-26. p.

A büntetőjog legújabb nemzetközi és hazai változásairól. Magyar Jog 1998/2. 65-73. p.

Új fejlődési irányok, avagy a tradicionális jogállami büntetőjog eróziója. Magyar Jog 1997/6. 333-337. p.

Jóvátétel mint a konfliktusfeloldó büntető igazságszolgáltatás egyik formája. Jogtudományi Közlöny 1993/3. 89-100. p.

Jóvátétel mint a konfliktusfeloldó büntető igazságszolgáltatás egyik formája. Kriminológiai Közlemények 1993/48. 4-36. p.

A büncselekmény áldozatának állami kártalanításáról. Magyar Jog 1993/4. 200-205. p.

A büntetőjog fejlödése Európában 1984-1986 között. Jogtudományi Közlöny 1989/4. 210-211.p.

Az észak-amerikai és a svéd kriminálpolitikai irányváltásról. Jogtudományi Közlöny 1983/11. 726-732. p. 